diagnostics and treatment levels of patients with STI. To study of biomaterial, selected from urogenital system of 198 patients with chronic STI. There were the method of PCR, amplificator DT-96, reagents of «Femoflor-16», praymers for the exposure of T. vaginalis, T. tenax and Pt. hominis. At 77 (38,8 \%) from 198 patients was fined: T. tenax - at 41 (20,7 \%), Pt. hominis - at 28 (14,1\%), T. vaginalis - at 8 (4\%). At 92,2\% patients with trihomonas invasion, in the urogenital system was find a growth of microflora, associated with BV. We used a system medicines for treatment ofurogenital system's defeats, caused the different types of trihomonas and microorganisms, associated with BV. For treartment of with chronic STI were choiced Seknidox (2 tabs one time per day, during 5 days) and Orcipol (1 tabs 2 times per day, during 10 days). As a result of treatment it was eliminaciya of trihomonas for 54 patients $(96,4 \%)$, normalization of microfloras' level for 31 patients $(57,4 \%)$. The decreasing of microflora's quantityfor 24 patients $(42,6 \%)$. The original method of treatment of urogenital system's defeats, caused the different types of trihomonas and microorganisms, associated with BV, is effective and can be recommended for empiric therapy of these diseases.

Key words: trihomonas; bacterial vaginosis; urogenital system; diagnostics; treatment.

УдК 616.65+616.686]-002-036/12-06-085:[616/69-008/1+616/999 DOI 10.31640/JVD.5-6.2018(19) Надійшла 25.12.2017

\author{
Т. П. КОРЖОВА, П. В. БАРДОВ, О. П. ШЕВЧЕНКО (Киів)
}

\title{
ВКЛЮЧЕННЯ ТІОТРІАЗОЛІНУ В СХЕМУ ЛІКУВАННЯ ХРОНІЧНОГО ПРОСТАТИТУ І ПРОСТАТОВЕЗИКУЛІТУ, УСКЛАДНЕНИХ ПОРУШЕННЯМ КОПУЛЯТИВНОЇ ТА РЕПРОДУКТИВНОї ФУНКЦІї
}

Національний медичний університет ім. О. О. Богомольця <trinitygreen.162014@gmail.com>

\begin{abstract}
Включення до комплексної патогенетичної терапї хворих на хронічний простатит та простатовезикуліт препаратів групи тіотріазоліну дозволить скоротити терміни лікування хворих, покращити медико-сочіальні показники їх життя та подовжити терміни ремісї.
\end{abstract}

Ключові слова: хронічний простатит; простатовезикуліт; тіотріазолін.

Вступ. Питання своєчасної діагностики уражень передміхурової залози останніми десятиліттями стали особливо актуальними, що обумовлено збільшенням захворюваності на хронічний простатит серед чоловіків молодого і середнього віку, а це призводить до зниження їх копулятивної та репродуктивної функцій. Відомо, що хронічний простатит із супутнім ураженням інших додаткових статевих залоз, зокрема сім'яних міхурців (везикуліт), придатків яєчок (епідидиміт), яєчок (орхіт), у 40-50 \% хворих чоловіків є причиною безплідного шлюбу.

Виникнення запальних уражень репродуктивної системи у чоловіків обумовлено інфікуванням сечостатевих шляхів рядом патогенних і умовно-патогенних мікроорганізмів. Значення інфекційних агентів (хламідії, гонококи, мікоплазма, уреаплазма, трихомонади, гарднерели, гриби роду Candida тощо) у виникненні урогенітальної інфекції досліджено досить детально. Разом з тим дослідження останніх років вказують на збільшення кількості змішаних (мікстінфекційних) уражень сечостатевого тракту, що спричинює зміни характеру їх клінічного перебігу і збільшення чисельності різнопланових ускладнень.

На розвиток і характер перебігу хронічного запалення сечостатевих органів, а також на виникнення ускладнень, зокрема копулятивного та репродуктивного характеру, впливають також порушення біохімічного складу секрету придаткових статевих залоз і стан місцевого (локального) імунітету [3, 10]. При цьому роль порушень місцевого імунного захисту і змін біохімічного складу секрету перед- 
міхурової залози та інших придаткових статевих залоз в патогенезі запальних захворювань статевих органів чоловіків і їх вплив на запліднювальні властивості еякуляту залишаються до кінця не з'ясованою та неповністю вивченою. Виникає також ряд питань про роль факторів місцевого імунітету репродуктивної системи у протиінфекційній резистентності організму при розвитку хронічного простатиту і простатовезикуліту.

У вітчизняній та зарубіжній спеціальній літературі традиційно розглядають дві теорії етіології хронічного ураження передміхурової залози та сім'яних міхурців (хронічний простатит, хронічний простатовезикуліт): інфекційну і неінфекційну (асептична).

Згідно з інфекційною теорією, захворювання розвивається внаслідок каналікулярного проникнення патогенних мікроорганізмів з уретри в тканини передміхурової залози і сім'яних міхурців через лімфатичні судинні анастомози та гематогенного шляху - внаслідок уретровенозного рефлюксу або через венозні та артеріальні анастомози, що спричинюють осідання в цих органах циркулюючих з кров'ю мікроорганізмів. До специфічних інфекційних агентів, що викликають ураження передміхурової залози і сім'яних міхурців, належать хламідії, гонококи, трихомонади, мікоплазми, уреаплазми, гриби роду Candida [2, 4]. Погляди дослідників на роль різних мікроорганізмів в етіології хронічного простатиту і простатовезикуліту досить суперечливі.

Ряд авторів висловлюють думку, що основними інфекційними агентами, які викликають запальне ураження репродуктивної системи у чоловіків, є умовнопатогенні мікроорганізми, що знаходяться в сечостатевих органах і кишечнику людини: стафілокок золотистий, стрептокок фекальний, кишкова паличка, протей, клебсієла тощо [4].

Разом $з$ тим виявлення бактерій у виділеннях з уретри і в секреті передміхурової залози неможливо об'єднувати з етіологією хронічного простатиту [7, 9]. Це обумовлено тим, що аналогічні мікроорганізми ізольовані від уретри і секрету передміхурової залози однаково часто у чоловіків як із симптомами хронічного простатиту, так і без них [9]. Крім того, результати бактеріоскопічних і бактеріологічних досліджень секрету передміхурової залози, отриманого під час їі масажу, можуть бути хибними, що пов'язано з його змішуванням з уретральним вмістом. Поряд з цим не виключена можливість персистування бактерій в передміхуровій залозі без запального процесу.

Популярна і теорія виникнення неінфекційного (асептичного) простатиту, до чинних факторів якого належать порушення дренування простатичних ацинусів (конгестія), застій крові у венах малого таза, імунологічні порушення, гормональні зміни, порушення іннервації, алергія, стиснення тканини передміхурової залози $[3,4]$.

Існує думка, що нині у 2/3 хворих на хронічний простатит етіологічним фактори є конгестія у венах малого таза [5, 9]. Тривалий венозний застій в передміхуровій залозі призводить до серозного набряку та інфільтрації їі тканини просякаючими із судин елементами білої крові. Внаслідок цього відбувається порушення метаболізму органа, що викликає хімічне подразнення його слизової оболонки і вихід з току крові лейкоцитів у порожнини залози. У подальшому може приєднуватись інфекція, що ускладнює перебіг захворювання [1].

A. I. Банев, А. I. Хаджилов [9] пов'язують хронічний простатит з хронічною інтоксикацією різними отрутами (нікотин, спиртні напої, морфін).

Доведено, що у 80-93 \% хворих на хронічний простатит відмічається суттєве зниження рівня тестостерону. Це призводить до гіперестрогенії, яка спричинює погіршення репаративних процесів і дистрофічні зміни в передміхуровій залозі.

Вказується також на роль імунних порушень в розвитку хронічного простатиту. Фундаментальні дослідження [6] показали, що імунізація лабораторних тварин суспензією тканини передміхурової залози дозволяє отримати сироватку, введення якої здоровим тваринам викликає деструктивні зміни в залозі за типом простатичного «алергозу». 
Про участь імунологічного фактора в розвитку хронічного простатиту свідчить поява в крові хворих на простатит аутоантитіл, які виникають як реакція на антигени клітин передміхурової залози за умови наявності в ній хронічного запалення $[2,6]$. Одним з морфологічних проявів аутоімунного процесу є так званий гранульоматозний простатит.

Таким чином, дотепер немає єдиної думки про провідну етіологічну роль вищенаведених факторів у виникненні хронічного простатиту.

Запальні захворювання статевих органів у чоловіків і їх наслідки мають провідне значення в генезі безпліддя порівняно з іншими факторами. Питома вага безплідних шлюбів у світі досягає 15-20 \% [8]. У половині випадків безпліддя є результатом патології органів репродуктивної системи в одного з подружжя. При цьому і у жінок і у чоловіків безпліддя зустрічається однаково часто.

Механізм виникнення патологічних змін репродуктивної системи складний і до кінця не вивчений. Більшість дослідників $[1,8]$ пов'язують зміни показників спермограми як із запальними захворюваннями репродуктивної системи у чоловіків, так і з перенесеною інфекцією у минулому. Разом з тим питання про значення хронічних запальних захворювань статевих шляхів як причини патології сперми і безпліддя ще не вирішене. Деякі дослідники стверджують, що латентна інфекція може бути виявлена у $40 \%$ чоловіків з безпліддям і розглядають їі як одну з найчастіших причин зниження фертильних властивостей еякуляту $[1,4]$. Інші автори вважають, що хронічні запальні захворювання сечостатевого тракту можна розглядати як причинний фактор інфертильності у менш ніж 10 \% чоловіків з безпліддям [1].

Як показують дослідження Ю. М. Ковальова, у хворих з лейкоспермією такі показники спермограми, як кількість сперматозоїдів у 1 мл, їх рухомість, відсоток нормальних форм, були суттево зміненими порівняно з практично здоровими чоловіками. Серед цих хворих патологічна концентрація гранулоцитів виявлена у $15 \%$. Автори роблять висновок, що така клітинна відповідь може негативно впливати на фертильні властивості еякуляту за рахунок цитотоксичної дії імунної системи.

Згідно з даними ряду авторів [1, 3], патоспермію при хронічних захворюваннях статевих органів у чоловіків виявлено у $33-82$ \% хворих. В одних випадках патоспермія тимчасова, в інших має стійкий характер, а в решти зміни сперми прогресивно наростають, в тому числі може розвинутись азоспермія.

Дослідження I. Ф. Юнди показали, що ступінь і частота порушень репродуктивної функції залежать від тривалості запального процесу в статевих органах. Цю думку підтримують інші автори [3], вказуючи на кореляцію між тривалістю захворювання і показниками еякуляту.

Ряд авторів $[1,7]$ висловлюють думку, що хвороби, що передаються статевим шляхом, суттєво не впливають на якість еякуляту. Разом з тим вони вказують, що зниження фертильних властивостей еякуляту було прямо пропорційним тривалості перебігу інфекцій статевих органів.

Таким чином, запальні захворювання статевих органів, які часто призводять до безпліддя у чоловіків (задній уретрит, простатит, везикуліт, куперит, орхіт, епідидиміт), обумовлені проникненням інфекційних агентів на фоні гемодинамічних порушень в органах малого таза.

Мета дослідження - оцінка ефективності удосконаленої нами комплексної терапії з включенням тіотріозаміну хронічного простатиту і простатовезикуліту, ускладнених порушеннями когулятивної та репродуктивної функцій.

Матеріали і методи. Патогенетична терапія обстежених нами хворих на хронічний простатит і простатовезикуліт включала заходи, спрямовані на усунення проявів конгестії в малому тазі, покращання відтоку застійного секрету з передміхурової залози та сім'яних міхурців, стимуляцію крово- і лімфообігу, а також нормалізацію функції передміхурової залози, сперматогенезу та усунення патогенетичних механізмів аутоагресії. 
До важливих факторів патогенезу хронічного простатиту, який, на нашу думку, потребує обов'язкової терапевтичної корекції, належить порушення мікроциркуляції в передміхуровій залозі (тромбоз венозної системи).

Однією з груп лікарських засобів, застосовуваних фахівцями для лікування хронічного простатиту, є препарати з протиішемічною і мебраностабілізуючою дією, зокрема тіатріазолін.

Застосування тіатріазоліну широко відоме фахівцям різних галузей, особливо його кардіо- і гепатопротекторні властивості, зокрема його мембраностабілізуюча активність добре вивчена і досить широко використовується в медичній практиці. 3 появою на українському ринку препарату Далмаксин у формі супозиторіїв для ректального застосування, діючою речовиною якого є тіотріазолін, з'явилася додаткова можливість більш широкого використовання його властивостей і в лікуванні хронічного простатиту.

При всмоктуванні в прямій кишці він виявляє протиішемічну, антиоксидантну, мембраностабілізуючу, імуномодулюючу і регенеруючу дії.

Завдяки цьому даний препарат підвищує ефективність будь-якої базисної терапії (в тому числі антибактеріальної), запобігає розвитку ускладнень, скорочує терміни лікування [5].

3 метою оцінки ефективності удосконаленої нами комплексної патогенетичної терапії хронічного простатиту і простатовезикуліту, ускладнених порушеннями копулятивної та репродуктивної функцій, а також порівняння її результатів 3 загальноприйнятими методами лікування обстежених хворих (132 пацієнти) розподілено на дві рівноцінні клінічні групи. Критеріями відповідного рівноцінного розподілу на клінічні групи були вік пацієнта, тривалість перебігу захворювання, клінічна форма ураження, а також скарги хворих на порушення копулятивної функції та результати дослідження у них показників спермограми.

До основної клінічної групи ввійшло 67 пацієнтів, серед яких у 23 показники спермограми відповідали нормоспермії, у 21 - олігоспермії І ступеня, у 14 - олігоспермії ІІ ступеня, у 7 - олігоспермії ІІІ ступеня і у 2 виявлено азоспермію.

Друга клінічна група (група порівняння) включала 65 хворих. При дослідженні спермограми у 22 пацієнтів цієї групи виявлено нормоспермію, у 20 - олігоспермію I ступеня, у 15 - олігоспермію II ступеня, у 6 - олігоспермію III ступеня і у 2 - азоспемію.

Для нормалізації порушень копулятивної та репродуктивної функцій хворим на хронічний простатит і простатовезикуліт (основна клінічна група) призначали ряд додаткових терапевтичних заходів. При цьому тактичні підходи до проведення цих терапевтичних заходів та їх обсяг були індивідуалізовані для кожного конкретного пацієнта з урахуванням ступеня і характеру статевих порушень, а також показників дослідження спермограми.

Хворим на хронічний простатит і простатовезикуліт (основна клінічна група), які скаржились на прискорене сім'явиверження, ми вважали за доцільне включення до комплексної терапії лікарських препаратів, терапевтична дія яких спрямована як на центральні (кора мозку, гіпоталамус, функціональні спинномозкові центри), так і на периферичні структури (аферентні та еферентні гілки рефлекторної дуги).

Важливим компонентом патогенетичної терапії хронічного простатиту і простатовезикуліту є терапевтичні заходи, спрямовані на покращання відтоку із статевих залоз. Для цього ми застосовували препарат з широким спектром терапевтичних ефектів - відновлення мікроциркуляції, протизапальна, імуномодулююча, мембраностабілізуюча, протиішемічна, антитиоксидантна, регенеративна дія далмаксин (діюча речовина тіотріазолін), який призначали хворим per rectum y формі ректальних свічок один раз на день (на ніч) протягом 20-30 днів.

Результати та іх обговорення. Проведення всебічного аналізу терапевтичної ефективності запропонованого нами патогенетичного і реабілітаційного методу лікування та традиційного методу терапії хронічного простатиту і простатовезикуліту, ускладнених порушеннями копулятивної та репродуктивної функцій, до- 
зволило виявити суттєві відмінності в отриманих результатах, що зумовило розподіл обстежених пацієнтів на відповідні підгрупи (згідно з вищевказаними критеріями).

Основна клінічна група включала 67 хворих, серед яких у 18 діагностовано катаральний простатит, у 28 - фолікулярний і у 21 - простатовезикуліт. До групи порівняння ввійшло 65 пацієнтів, серед яких у 18 діагностовано катаральний простатит, у 26 - фолікулярний і у 21 - простатовезикуліт.

Згідно із запропонованими нами критеріями оцінки ефективності лікування, у 58 (86,6 \%) з 67 пацієнтів основної клінічної групи досягнуто повне клінічне виліковування з нормалізацією запліднювальних властивостей еякуляту, у 7 $(10,4$ \%) - виліковування з відносною нормалізацією клініко-лабораторних показників і у 1 (1,5 \%) - виліковування з частковим збереженням клінічної симптоматики при незначній нормалізації лабораторних показників.

Серед 65 чоловіків, які отримували традиційну терапію (група порівняння), у 23 (35,4 \%) досягнуто повне клінічне виліковування, у 33 (50,5 \%) - виліковування з відносною нормалізацією клініко-лабораторних показників, у 6 (9,2 \%) виліковування з частковим збереженням клінічної симптоматики при незначній нормалізації лабораторних показників і у 3 (4,6 \%) не досягнуто етіологічного виліковування при одночасній відсутності терапевтичного покращання та збереженні суттєвих порушень показників запліднювальних властивостей еякуляту (азоспермія).

Показники запліднювальних властивостей еякуляту обстежених хворих на хронічний простатит після застосування комплексного удосконаленого методу лікування та після традиційного лікування наведено в таблиці.

\section{Показники запліднювальних властивостей еякуляту обстежених хворих} на хронічний простатит після лікування

\begin{tabular}{|c|c|c|c|c|c|c|c|c|c|c|c|c|}
\hline \multirow{3}{*}{ Форма простатиту } & \multicolumn{10}{|c|}{ Характер еякуляту обстежених чоловіків } & \multirow{2}{*}{\multicolumn{2}{|c|}{$\begin{array}{l}\text { Всього } \\
\text { хворих }\end{array}$}} \\
\hline & \multicolumn{2}{|c|}{$\begin{array}{l}\text { нормоспер- } \\
\text { мія }\end{array}$} & \multicolumn{2}{|c|}{$\begin{array}{c}\text { олігоспермія } \\
\text { I ступеня } \\
\end{array}$} & \multicolumn{2}{|c|}{$\begin{array}{c}\text { олігоспермія } \\
\text { II ступеня } \\
\end{array}$} & \multicolumn{2}{|c|}{\begin{tabular}{c|} 
олігоспермія \\
III ступеня \\
\end{tabular}} & \multicolumn{2}{|c|}{$\begin{array}{l}\text { азоспер- } \\
\text { мія }\end{array}$} & & \\
\hline & $\begin{array}{l}\text { абс. } \\
\text { од. }\end{array}$ & $\%$ & $\begin{array}{l}\text { абс. } \\
\text { од. }\end{array}$ & $\%$ & $\begin{array}{l}\text { абс. } \\
\text { од. }\end{array}$ & $\%$ & $\begin{array}{l}\text { абс. } \\
\text { од. }\end{array}$ & $\%$ & $\begin{array}{c}\text { абс. } \\
\text { од. }\end{array}$ & $\%$ & $\begin{array}{l}\text { абс. } \\
\text { од. }\end{array}$ & $\%$ \\
\hline & \multicolumn{12}{|c|}{ Застосування комплексного удосконаленого методу лікування } \\
\hline $\begin{array}{l}\text { Катаральний } \\
(n=18)\end{array}$ & 17 & 25,4 & 1 & 1,5 & - & 0 & - & 0 & - & 0 & 18 & 26,9 \\
\hline $\begin{array}{l}\text { Фолікулярний } \\
(n=28)\end{array}$ & 25 & 67,3 & 2 & 3 & 1 & 1,5 & - & 0 & - & 0 & 28 & 41,8 \\
\hline $\begin{array}{l}\text { Простатовезикуліт } \\
(n=21)\end{array}$ & 16 & 23,9 & 4 & 6 & - & 0 & 1 & 1,5 & - & 0 & 21 & 31,3 \\
\hline \multirow[t]{2}{*}{ Всього } & 58 & 86,6 & 7 & 10,4 & 1 & 1,5 & 1 & 1,5 & - & 0 & 67 & 100 \\
\hline & \multicolumn{12}{|c|}{ Застосування традиційного методу лікування } \\
\hline $\begin{array}{l}\text { Катаральний } \\
(n=18)\end{array}$ & 12 & 18,5 & 4 & 6,2 & 2 & 3,1 & - & 0 & - & 0 & 18 & 27,7 \\
\hline $\begin{array}{l}\text { Фолікулярний } \\
(n=28)\end{array}$ & 9 & 13,8 & 9 & 13,8 & 6 & 9,2 & 2 & 3,1 & - & 0 & 26 & 40 \\
\hline $\begin{array}{l}\text { Простатовезикуліт } \\
(n=21)\end{array}$ & 2 & 3 & 7 & 10,8 & 5 & 8 & 4 & 6,2 & 3 & 4,6 & 21 & 32,3 \\
\hline Всього & 23 & 35,4 & 20 & 30,8 & 13 & 20 & 6 & 9,2 & 3 & 4,6 & 65 & 100 \\
\hline
\end{tabular}

Вищенаведені результати клінічного обстеження і дослідження запліднювальних властивостей еякуляту в пацієнтів у динаміці лікування вказують на необхідність проведення комплексної патогенетичної терапії, спрямованої на нормалізацію порушень стану місцевого кровообігу з включенням препаратів протиішемічної дії для забезпечення нормального функціонування статевої системи та функціонування передміхурової залози й інших придаткових статевих залоз. 
Висновки. Комплексну терапію хронічного простатиту і простатовезикуліту, ускладнених порушеннями копулятивної та репродуктивної функцій, слід проводити індивідуалізовано із застосуванням відповідних етіотропних антибактеріальних засобів, згідно з етіологією, а також з урахуванням моно- або мікстінфекційного ураження. Патогенетична терапія хронічного простатиту і простато- везикуліту, ускладнених статевими порушеннями, також передбачає індивідуалізований підхід. Зокрема, рекомендується комплекс терапевтичних заходів, спрямованих на усунення проявів конгестії в малому тазі, покращання відтоку застійного секрету з передміхурової залози та сім'яних міхурців, стимуляцію крово- і лімфообігу, а також на нормалізацію функції передміхурової залози, сперматогенезу. Вважаємо за доцільне застосування препарату з широким спектром терапевтичних ефектів - відновлення мікроциркуляції, протизапальна, імуномодулююча, мембраностабілізуюча, протиішемічна, антитиоксидантна, регенеративна дія - далмаксин (діюча речовина тіотріазолін), який рекомендовано призначати хворим у формі ректальних свічок 1 раз на день (на ніч) протягом 20-30 днів. Включення до комплексної патогенетичної терапії хворих на хронічний простатит та простатовезикуліт препаратів групи тіотріазоліну дозволить скоротити терміни лікування хворих, покращити медико-соціальні показники їх життя та подовжити терміни ремісії.

\section{С пи сок лі т ера тури}

1. Адаскевич В. П. Инфекции, передаваемые половым путём. - М.: Мед. кн., 2009. $413 \mathrm{c}$.

2. Акулович А. И. Оценка комплексного лечения больных хроническим простатитом по тестам функциональной диагностики // Здравоохранение Белоруссии. 2004. - № 3. - С. 69-71.

3. Афонин А. В. Диагностика и лечение больных хроническим уретропростатитом, осложнённым инфекциями урогенитального тракта: Автореф. дис. ... канд. мед. наук. - М., 1991. - 17 с.

4. Бабюк И. А. Комплексне лікування хворих на хронічний простатит з використанням низькоенергетичного гелій-неонового лазеру і ультразвукового дослідження передміхурової залози: Автореф. дис. ... канд. мед. наук. - Харків, 1992. - 25 с.

5. Літус О. I. Особливості місцевого імунітету при різних клінічних формах інфекційного простатиту та патогенетично обумовлена терапія захворювання: Автореф. дис. ... канд. мед. наук. - К., 1996. - 21 с.

6. Лопаткин Н. А., Борисенко Н. И., Городеuкая С. Б., Кондратьева Е. М. Дифференциальная диагностика аллергического простатита // Урология и нефрология. 2010. - № 2. - С. 17-20.

7. Люлько А. В. Заболевания предстательной железы. - К.: Здоровья, 1984. - 280 с.

8. Brandes D., Bourne G. Histochemistry of some aspects of prostate pathology // In: Biol. Prostata and relat tissues. - Bethesda, 2003. - P. 29-41. 9. Meares E. M. Prostatitis-acute and chronic // Prostatic disorders / Eds. D. F. Paulson, Lea and Febiger. - Philadelphia, 2009. - P. 71-106.

10. Wei S. G., Wang L. F., Miao S. Y. et al. Scientific fertility with antisperm antibodies // J. Androl. 1994. - Vol. 32, N3. - P. 251-262.
1. Adaskevich V.P. Infekcii, peredavaemye polovym putem. - M.: Med. kn., 2009. - 413 s.

2. Akulovich A. I. Ocenka kompleksnogo lecheniya bol'nyh hronicheskim prostatitom po testam funkcional'noj diagnostiki // Zdravoohranenie Belorussii. - 2004. - № 3. S. 69-71.

3. Afonin A. V. Diagnostika i lechenie bol'nyh hronicheskim uretroprostatitom, oslozhnennyym infekciyami urogenital'nogo trakta: Avtoref. dis.... kand. med. nauk. - M., 1991. $17 \mathrm{~s}$.

4. Babyuk I. A. Kompleksne likuvannya hvorih na hronichnij prostatit $\mathrm{z}$ vikoristannyam niz'koenergetichnogo gelij-neonovogo lazeru i ul'trazvukovogo doslidzhennya peredmihurovoï zalozi: Avtoref. dis. ... kand. med. nauk. - Harkiv, 1992. - 25 s.

5. Litus O. I. Osoblivosti miscevogo imunitetu pri riznih klinichnih formah infekcijnogo prostatitu ta patogenetichno obumovlena terapiya zahvoryuvannya: Avtoref. dis. ... kand. med. nauk. - K., 1996. - $21 \mathrm{~s}$.

6. Lopatkin N. A., Borisenko N. I., Gorodeckaya S. B., Kondrat'eva E. M. Differencial'naya diagnostika allergicheskogo prostatita // Urologiya i nefrologiya. 2010. - № 2. - S. 17-20.

7. Lyul'ko A.V.Zabolevaniya predstatel'noj zhelezy. - K.: Zdorov'ya, 1984. - 280 s. tily with antisperm antibodies //J. Androl. 
ВКЛЮЧЕНИЕ ТИОТРИАЗОЛИНА В СХЕМУ ЛЕЧЕНИЯ ХРОНИЧЕСКОГО

ПРОСТАТИТА И ПРОСТАТОВЕЗИКУЛИТА, ОСЛОЖНЁННЫХ НАРУШЕНИЕМ КОПУЛЯТИВНОЙ И РЕПРОДУКТИВНОЙ ФУНКЦИИ

Т. П. Коржова, П. В. Бардов, Е. П Шевченко (Киев)

Включение в комплексную патогенетическую терапию больных хроническим простатитом и простатовезикулитом препаратов группы тиотриазолина позволит сократить сроки лечения больных, улучшить медико-социальные показатели их жизни и продлить сроки ремиссии.

Ключевые слова: хронический простатит; простатовезикулит; тиотриазолин.

\title{
USING OF THIOTRIAZOLIN IN TREATMENT OF CHRONIC PROSTATITIS AND PROSTATOVESYKULITIS COMPLICATED DISORDERS COPULATIVE AND REPRODUCTIVE FUNCTIONS
}

\author{
T. P. Korzova, P. V. Bardov, O. P. Shevchenko (Kiyv, Ukraine) \\ Bogomolets National Medical University
}

The inclusion in complex pathogenetic therapy of patients with chronic prostatitis and prostatovesiculitis preparations of thiotriazolin will shorten treatment, improve medico-social indicators of life of patients and prolong remission.

Key words: chronic prostatitis; prostatovesiculitis; thiotriazolin.

\section{ЕКСПЕРИМЕНТАЛЬНЕ ДОСЛІДЖЕННЯ}

\section{I. В. КЕРЕЧАНИН (Київ)}

\section{УЛЬТРАСТРУКТУРА КРОВОНОСНИХ КАПІЛЯРІВ ВИЛОЧКОВОЇ ЗАЛОЗИ ЩУРІВ У НОРМІ ТА ПІД ВПЛИВОМ МЕТИЛТРЕТБУТИЛОВОГО ЕФІРУ В ЕКСПЕРИМЕНТІ}

Кафедра анатомії людини, топографічної анатомії та оперативної хірургії (зав. - проф. В. І. Талько) Приватного вищого навчального закладу «Київський медичний університет УАМН»<kerechaniniv@ukr.net>

У статті наведено аналіз данних про будову гемомікрощиркуляторного русла щурів під впливом різних доз метилтретбутилового ефіру (500 мг/к2, $50 \mathrm{~m} / \kappa 2,5 \mathrm{мг} / \kappa 2,0,5 \mathrm{~m} / \kappa 2)$. Вивчали структуру епидотеліоцитів гемомікроциркуляторного русла вилочкової залози шурів на 3-, 8-, 15-, 22-, 60-ту добу експерименту. Дія метилтретбутилового ефіру проявляється у надмірному рівні апоптозу лімфоцитів та зниженні фагоцитарної активності макрофагів, які піддаються некрозу у вилочковій залозі.

Ключові слова: вилочкова залоза; метилтретбутиловий ефір; апотоз.

Вступ. Кількість захворювань, пов’язаних з патологією імунної системи, останніми роками значно збільшилась серед населення. Клініцисти пояснюють ці дані станом екології, зокрема забрудненням води як невід’ємного фактора життєдіяльності організму [1]. Одним з джерел забруднення грунтових вод $є$ продукти крекінгу нафти, нафтопереробки та складові моторного палива. В зв’язку із збіль- 